\title{
Influence of the Level of Financial Development on OFDI in China
}

\author{
Peiyi Chen \\ College of Economics, Jinan University, Guangzhou, China \\ Email: rosechenpy@sina.com
}

How to cite this paper: Chen, P.Y. (2018) Influence of the Level of Financial Development on OFDI in China. American Journal of Industrial and Business Management, 8, 327-340.

https://doi.org/10.4236/ajibm.2018.82020

Received: January 2, 2018

Accepted: February 20, 2018

Published: February 23, 2018

Copyright $\odot 2018$ by author and Scientific Research Publishing Inc. This work is licensed under the Creative Commons Attribution International License (CC BY 4.0).

http://creativecommons.org/licenses/by/4.0/

(c) (i) Open Access

\begin{abstract}
Outward Foreign Direct Investment (OFDI) is influenced by many factors. In these factors, the impact of the financial development of the investing country is very important and obvious. An important support for an enterprise to make OFDI is to get a sufficient source of funding, and the source of funding depends on the degree of development of domestic financial market. From the early research, we can find that OFDI in developing countries, at least to some extent, is the result of economic structural improvements and financial innovations. Taking China as an example, this paper studies the role of developing countries in the level of financial development in OFDI. By using the panel data of 30 provinces and autonomous regions in China during the five-year period from 2010 to 2014, we want to examine the development of financial markets in various regions impact on China's outward foreign direct investment.
\end{abstract}

\section{Keywords}

Outward Foreign Direct Investment, Financial Development

\section{Introduction}

Nowadays, developing countries are increasingly becoming an important force in the world's outward foreign direct investment. Searching data and information from WIND financial database and CCER database, we found something important that could show OFDI's importance in the world economy. The share of developing countries outward foreign direct investment flows in the world's total outward foreign direct investment flows rose from 3.1\% in 1981 to $30.6 \%$ in 2011. And the stock of that rose from $12.5 \%$ to $22.5 \%$. In the case of developing countries in Asia, OFDI constitutes the most important part of the developing countries in the world. In 2014, the OFDI from developing countries in Asia ac- 
counted for almost $80 \%$ of the total outward foreign direct investment in all developing countries. Outward foreign direct investment (OFDI) in Asia comes mainly from NIEs. As an important member of Newly Industrialized Economies, China always has played an increasingly important role in the world's outward foreign direct investment. The World Investment Report released by UNCTAD shows that, by the end of 2012, the flows of OFDI by Chinese enterprises, which accounted for $6.3 \%$ of the world's flows, had jumped to the third place in the world and its stocks (about 2.3\%) had also ranked seventh in the world, just as it had become an important pillar of global outward foreign direct investment. Under this circumstance, one striking issue is why the outward foreign direct investment of Chinese enterprises has increased so rapidly? What is the key factor and driving force? Many scholars attribute it to government policies that the government dominates China's outward foreign direct investment. It is quite natural and understandable to hold this view because Chinese government is one of the most important actors in economic activity that promotes and controls economic development. According to the data, in the initial period of direct investment abroad, state-owned enterprises did account for the majority of investment, while enterprises which are private-owned accounted for only $1.5 \%$ of total investment [1] [2]. However, by searching the data in recent years, intuition is not always correct. A conclusion we can make that the proportion of state-owned enterprises in outward foreign direct investment is decreasing year by year. It is very obviously that some other important factors must play an important role in promoting ODFI in China. Therefore, this paper from another perspective, that is, the development of local financial markets, to study its impact on China's outward foreign direct investment.

\section{Literature Review}

Since this paper mainly studies the influence of financial development factors on OFDI, we no longer cite the government-led. Instead, we study the OFDI from the perspective of financial development. An important support for an enterprise to make outward foreign direct investment is a sufficient source of funding, and the source of funding depends on the degree of development of the domestic financial market. At the same time, however, domestic financial development will also increase domestic investment opportunities and reduce the attractiveness of foreign markets. This shows that financial development may be a doubleedged sword for China's outward foreign direct investment [3].

In the study of development economics, the role of financial development has gained widespread acceptance and is considered as one of the major drivers of economic development (McKinnon, 1973; Beck and Levine, 2004) [4] [5]. Dunning's theory (1981) of investment and development cycle in international production shows that the stage or level of economic development of a country is directly related to the scale of foreign direct investment [6]. That is, the higher the level of economic development, the larger the scale of foreign direct invest- 
ment. At the same time, foreign direct investment can indirectly increase the scale of OFDI by promoting economic growth. Berman \& Hericourt (2008) Using business studies from different countries, it was found that financing development significantly affect firm export decisions [7]. Manova (2013) found from theoretical studies that the cross-border differences in financial development and financing constraints have affected the thresholds and export performance of enterprises entering the export market [8].

As a developing country, the low degree of financial development is considered as the main factor that restricts the investment of enterprises in our country, especially the investment of private enterprises (Shen Hongbo et al. 2010) [9]. Among the outward foreign direct investment of enterprises in our country, credit constraints and insufficient funds are also considered as the main obstacles, especially for private-sector foreign direct investment [10]. Guan Jiancheng (2007) and Lin Zhihong et al. (2012) use time series data through a home country perspective to analysis averge GDP, exports, attracting foreign investment, technical capabilities, foreign trade, real exchange rate of RMB, and average worker salary in manufacturing industry and other macroeconomic variables in order to know how they effect in China's outward foreign direct investment [11] [12]. Guojie et al. (2010) based on the world's 41 major countries panel data, through regression, using savings, corporate governance and financial structure as variables to find the relationship between outward foreign direct investment. They thought a country's level of OFDI is mainly affected by the country's total social savings, the level of economic development and the degree of trade. It shows a significant positive impact [13]. Yu Chao et al. (2011) used the data of China's provincial panel to empirically analyze the impact of trade level, economic development level, technological capability, industrial structure and employment structure on China's foreign direct investment [14]. Tao Pan (2013) and Yang Ting et al. (2014) thought that the government should increase the support of outward foreign direct investment made by financial development in the construction of policy system to promote foreign direct investment [15] [16]. Wang Wei (2013) found that both using the stock and active as financial indicators can significantly promote OFDI in a country [17]. These views are based on the premise that the improvement of the degree of financial development not only increases the financial resources but also enhances the allocation efficiency of financial resources so that it can provide adequate and effective financial support for OFDI and promote it effectively.

As the core of modern economy, OFDI is one of the most important activities in the trend of global economic globalization and is inevitably affected by the factors of financial development [18]. Through an analysis of the literature on the influencing factors of home-country on China's outward foreign direct investment, we can find there are still few empirical studies on the two aspects: First, the data are mainly based on the use of time-series data at the national lev$\mathrm{el}$, it is very rare to use panel data at the provincial level in analysis [19]. Second, 
the analysis of the impact of influencing factors such as economic development and more indicators are mainly joined to the variables, but the financial-related variables are few. Based on it, this paper uses the provincial panel data and some financial-related variables to empirically study the impact of financial development on China's OFDI.

\section{Research Methods and Sample Selection}

\subsection{Sample Selection}

In this paper, we use provincial total data, all the data come from official agencies. There are differences in the level of financial development in different regions. Providing opportunities for testing the role of financial markets, we think provincial data may be a better choice and instrument to examine the role of financial markets [20]. The sample data covers 25 provinces and autonomous regions in China with a range of 5 years (2010-2014). Among them, Guizhou, Gansu, Ningxia, Qinghai and Tibet Autonomous Region were excluded due to little or no direct data on outward direct foreign investment during the sample period. The selection of these five years was mainly due to the qualitative and high development of our country's outward foreign direct investment during the period, both in terms of the total investment and the proportion of investment. In addition, it has been a long time since the global financial crisis, and the adverse effects on the financial crisis are slowing down and recessing. All the data of outward foreign direct investment of enterprises comes from China Foreign Investment Statistics Bulletin released by the Ministry of Commerce, and we just select the sample we needed from the year 2010 to 2014. And the data of financial development are sorted according to China Financial Yearbook, China Statistical Yearbook and National Bureau of Statistics website. Other data are from the WIND, CSMAR and RESSET financial database. Detailed data source see the next part of the variable description.

\subsection{Research Methods}

In this paper, we use a combination of theoretical analysis and empirical analysis of research methods. Firstly, we summarize the research situation of predecessors, define the basic concepts and make a normative analysis on the mechanism of the degree of financial development on OFDI. After that, it empirically tests the relationship between the level of financial development and OFDI through theoretical analysis and research hypothesis. That is to improve the reliability of the conclusions of the study. In the aspect of theoretical analysis, we sort out the existing literature, put forward the entry point and perspective of this study. In the empirical research, we establish a multiple regression model to regress the variables that represent the degree of financial development to explore the specific impact of each indicator on the OFDI. A detailed explanation of each indicator could be seen in next section. 


\section{Empirical Methods}

This paper refers to empirical methods from these scholars: Yu Guansheng, Wang Wei and Huang Zhiyong. We establish the following multiple regression model [21]:

$$
\begin{aligned}
\ln O F D I_{i t}= & \alpha_{0}+\alpha_{1} F D_{i t}+\alpha_{2} \ln P G D P_{i t}+\alpha_{3} \ln E X_{i t} \\
& +\alpha_{4} \ln F I A_{i t}+\alpha_{5} \ln S A V E_{i t}+u_{i}+v_{t}+\varepsilon_{i t}
\end{aligned}
$$

The following is the specific meaning of each variable.

1) Explained variable

$\ln O F D I_{i t}$ represents the logarithm of the OFDI flows $(\$ 10,000)$ in area $i$ in year $t$.

2) Explanatory variables

$F D_{i t}$ indicates the financial development index for year $t$ in area $i$. There are four main indicators here:

$F D_{1}$ : Private credit to GDP ratio

$F D_{2}$ : Stock market capitalization to GDP ratio

$\mathrm{FD}_{3}$ : Loan balance of financial institutions as a share of GDP

$F D_{4}$ : Loan balance of non-financial institutions as a share of GDP

In this paper, the level of financial development is the most important explanatory variable. We selects four indicators to measure the level of financial development in a country in different directions: the ratio of private credit to GDP represents the overall level of development of the private credit market; the ratio of market capitalization to GDP in the stock market represents the measurement of the size of the capital stock market; Financial Institutions Loan Balance as a Percentage of GDP and Non-Financial Institution Loan Balance as a Percentage of GDP represents sources of funding for government and non-government financial and non-financial institutions, assesses the level of overall financial development in a region and represents the development of a large credit market condition. The more symmetrical information between the providers and users of funds in the developed credit market and the stock market can effectively reduce the risk. From the perspective of asset demand, the developed stock market can provide more portfolio options and hedges. The greater the risk of overseas direct investment is effectively reduced, that is to say, the more comprehensive insurance is provided. In another terms of asset supply, a sound credit market and capital market can capitalize more output, so that, it will increase credit markets and stocks market supply, also illustrates the prosperity of financial markets.

$\ln P G D P_{i t}$ represents the logarithm of per capita GDP (100 million yuan) in year $t$ in area $i$. Our purpose is to examine the impact of economic size on OFDI in the region to reflect the level of economic development. According to Dunning's five-stage theory of net foreign direct investment, the extent to which a country participates in international direct investment is closely linked to the country's level of economic development. In empirical test, many scholars both 
at home and abroad have concluded that there is a positive correlation between OFDI and economic development. This article refers to the method of Dunning, taking the logarithm of per capita GDP value as the economic development level.

$\ln S A V E_{i t}$ represents the level of savings in area $i$ in year $t$. The relatively high level of savings in our country constitutes a very cheap source of financial capital for our country's foreign direct investment. The higher the level of savings, the more investment capital will be generated through the savings investment transformation mechanism of the banking system, and the corresponding enterprises will be able to obtain higher investment capital at a lower cost, which will further promote China's outward foreign direct investment. This paper measures the level of saving by deposit savings in each province.

$\ln F I A_{i t}$ represents the logarithm of the use of foreign capital flow in area $\mathrm{i}$ in year $t$. Investments from foreign countries will have a significant impact on domestic enterprises's outward foreign direct investment, which may also have a significant impact on overseas direct investment in host countries through various channels, including spillover effect, capital effect, human capital effect and labor wage effect.

$\ln E X_{i t}$ represents the logarithm of the export trade (million US dollars) in area $i$ in year $t$. The reason for joining this variable is that more studies have found that export trade is the forerunner of OFDI. In this paper, the ratio of export to GDP is used to measure the level of regional economic openness.

$u_{i}$ and $v_{t}$ respectively stand for regional and time variables.

$\varepsilon_{i t}$ is residual.

Table 1 explained the detailed definition of each variable.

Table 1. Variables definition.

\begin{tabular}{|c|c|c|c|}
\hline Research object & Variables & Meaning & Data sources \\
\hline ODFI & $\operatorname{lnOFDI}$ & $\begin{array}{l}\text { The logarithm of the OFDI } \\
\text { flows }(\$ 10,000)\end{array}$ & $\begin{array}{c}\text { China Foreign Investment } \\
\text { Statistics Bulletin (2010-2014) }\end{array}$ \\
\hline $\begin{array}{l}\text { The financial } \\
\text { development index } 1\end{array}$ & $\mathrm{FD}_{1}$ & Private credit to GDP ratio & $\begin{array}{l}\text { China Statistical Yearbook } \\
\qquad(2010-2014)\end{array}$ \\
\hline $\begin{array}{c}\text { The financial } \\
\text { development index } 2\end{array}$ & $\mathrm{FD}_{2}$ & $\begin{array}{c}\text { Stock market capitalization to } \\
\text { GDP ratio }\end{array}$ & $\begin{array}{c}\text { China Statistical Yearbook } \\
(2010-2014)\end{array}$ \\
\hline $\begin{array}{c}\text { The financial } \\
\text { development index } 3\end{array}$ & $\mathrm{FD}_{3}$ & $\begin{array}{c}\text { Loan balance of financial } \\
\text { institutions as a share of GDP }\end{array}$ & $\begin{array}{c}\text { China Statistical Yearbook } \\
(2010-2014)\end{array}$ \\
\hline $\begin{array}{c}\text { The financial } \\
\text { development index } 4\end{array}$ & $\mathrm{FD}_{4}$ & $\begin{array}{l}\text { Loan balance of non-financial } \\
\text { institutions as a share of GDP }\end{array}$ & $\begin{array}{c}\text { 1) China Statistical Yearbook } \\
(2010-2014)\end{array}$ \\
\hline $\begin{array}{c}\text { The level of economic } \\
\text { development }\end{array}$ & $\ln \mathrm{PGDP}$ & $\begin{array}{l}\text { The logarithm of per capita } \\
\text { GDP (100 million yuan) }\end{array}$ & $\begin{array}{c}\text { National Bureau of Statistics } \\
\text { website }\end{array}$ \\
\hline Savings level & $\operatorname{lnSAVE}$ & $\begin{array}{l}\text { The logarithm of every } \\
\text { provincial savings }\end{array}$ & $\begin{array}{l}\text { China Business Statistics } \\
\text { Yearbook (2010-2014) }\end{array}$ \\
\hline $\begin{array}{l}\text { Attract foreign } \\
\text { investment }\end{array}$ & $\operatorname{lnFIA}$ & $\begin{array}{l}\text { The logarithm of the use of } \\
\text { foreign capital }\end{array}$ & $\begin{array}{c}\text { China Financial } \\
\text { Yearbook (2010-2014) }\end{array}$ \\
\hline Economic openness & $\ln E X$ & $\begin{array}{l}\text { The logarithm of the export } \\
\text { trade }\end{array}$ & $\begin{array}{c}\text { National Bureau of Statistics } \\
\text { website }\end{array}$ \\
\hline
\end{tabular}




\section{Empirical Analysis}

\section{1) Empirical test}

We put the sample data to stata for empirical analysis.

Table 2 lists the results of descriptive statistics

From the descriptive statistics, we can find that there are significant differences between the two countries in the area of outward foreign direct investment. At the same time, the levels of financial development in various provinces are also uneven. There are significant and huge differences, which are reflected in the ratio of private credit to GDP, stock market capitalization to GDP, loan balance of financial institutions as a percentage of GDP, loan balance of non-financial institutions as a percentage of GDP. They have strong differences reflected in the maximum and minimum values.

For panel data estimation, there are some commonly used methods, including fixed-effect model, random effects model and mixed effects model. Firstly, we can exclude the use of mixed effects model because the cross-section of sample data is almost all provinces in the country, not a small sample selected from large sample. In addition, the mixed effects model also ignores the differences between provinces so that the results from it can not give a good explanation of this problem. As for, the way to choose fixed effects or random effects model is decided by Hausman test. The results of Hausman test may indicate which model is better and more suitable to empirical research. Table 3 lists the Hausman test results.

As can be seen from the Table 3, the four models are applicable fixed-effects model. Then, we use STATA for making detailed panel data regression analysis. The results obtained are given in Table 4. The model 1 uses the ratio of private credit to GDP in each province of China in order to express the depth indicators of financial development. It is dedicated to analyze the degree of marketization of credit funds allocated to China's outward foreign direct investment. As a comparison, and then we introduce separately the other three indicators above

Table 2. Descriptive statistics.

\begin{tabular}{cccccc}
\hline Variables & Observations & Mean & variance & Minimum & Maximum \\
\hline $\ln$ OFDI & 150 & 8.259 & 3.104 & 0.216 & 15.48 \\
$\ln$ PGDP & 132 & 6.153 & 1.81 & 2.11 & 16.51 \\
$\operatorname{lnEX}$ & 136 & 4.224 & 0.517 & -1.723 & 10.59 \\
$\ln \mathrm{FIA}$ & 121 & 8.702 & 1.443 & 1.006 & 4.371 \\
$\ln \mathrm{SAVE}$ & 133 & 1.256 & 1.521 & -0.045 & 5.007 \\
$\mathrm{FD}$ & 153 & 2.238 & 0.124 & 0.002 & 9.101 \\
$\mathrm{FD}_{2}$ & 126 & 2.519 & 2.505 & -5.117 & 5.967 \\
$\mathrm{FD}_{3}$ & 145 & 1.334 & 3.015 & -3.209 & 11.003 \\
$\mathrm{FD}_{4}$ & 140 & 3.326 & 0.114 & 0.136 & 7.664 \\
\hline
\end{tabular}

Note: In this paper, all test result is obtained using stata12 software. 
Table 3. Hausman test results.

\begin{tabular}{ccccc}
\hline & \multicolumn{4}{c}{ Test indicators } \\
\cline { 2 - 5 } & Chi.sq statistic & Chi.sq df & Prob. & Selected model \\
\hline $\mathrm{FD}_{1}$ & 30.719882 & 5.8 & 0.001 & Fixed effect model \\
$\mathrm{FD}_{2}$ & 31.706525 & 5.5 & 0.020 & Fixed effect model \\
$\mathrm{FD}_{3}$ & 30.064112 & 6.0 & 0.001 & Fixed effect model \\
$\mathrm{FD}_{4}$ & 33.199601 & 5.8 & 0.000 & Fixed effect model \\
\hline
\end{tabular}

Table 4. Model variables regression results.

\begin{tabular}{|c|c|c|c|c|}
\hline Variables & Model1 & Model2 & Model3 & Model4 \\
\hline Intercept & $\begin{array}{c}-28.3025^{* * *} \\
(-12.1135)\end{array}$ & $\begin{array}{c}-25.6215^{\star * *} \\
(11.9802)\end{array}$ & $\begin{array}{c}-22.3324^{* * *} \\
(-8.4594)\end{array}$ & $\begin{array}{c}-28.0016^{* * *} \\
(-10.5001)\end{array}$ \\
\hline $\ln$ PGDP & $\begin{array}{c}2.1540^{\star * *} \\
(5.3852)\end{array}$ & $\begin{array}{c}2.0646^{* * *} \\
(5.1787)\end{array}$ & $\begin{array}{c}3.5689^{\star * *} \\
(4.0025)\end{array}$ & $\begin{array}{c}2.5111^{\star * *} \\
(4.1923)\end{array}$ \\
\hline $\operatorname{lnEX}$ & $\begin{array}{l}0.1096^{* *} \\
(2.3729)\end{array}$ & $\begin{array}{l}0.0246^{* *} \\
(3.0025)\end{array}$ & $\begin{array}{l}0.0077^{\star *} \\
(2.2526)\end{array}$ & $\begin{array}{l}0.0605^{\star *} \\
(1.5804)\end{array}$ \\
\hline $\operatorname{lnFDI}$ & $\begin{array}{l}0.3324^{\star *} \\
(2.6093)\end{array}$ & $\begin{array}{l}0.3201^{\star *} \\
(1.2641)\end{array}$ & $\begin{array}{c}0.2208^{\star * *} \\
(1.0529)\end{array}$ & $\begin{array}{c}0.2136^{\star * *} \\
(1.2093)\end{array}$ \\
\hline $\operatorname{lnSAVE}$ & $\begin{array}{c}0.6074^{\star \star \star} \\
(1.1257)\end{array}$ & $\begin{array}{l}0.7913^{*} \\
(3.3069)\end{array}$ & $\begin{array}{l}0.9641^{\star} \\
(3.4991)\end{array}$ & $\begin{array}{l}0.8372^{\star \star} \\
(5.5025)\end{array}$ \\
\hline $\mathrm{FD}_{1}$ & $\begin{array}{l}0.0089^{\star *} \\
(1.2574)\end{array}$ & & & \\
\hline $\mathrm{FD}_{2}$ & & $\begin{array}{c}0.1165^{* * *} \\
(1.6692)\end{array}$ & & \\
\hline $\mathrm{FD}_{3}$ & & & $\begin{array}{l}0.0215^{*} \\
(2.3741)\end{array}$ & \\
\hline $\mathrm{FD}_{4}$ & & & & $\begin{array}{l}0.0034^{*} \\
(1.0315)\end{array}$ \\
\hline $\begin{array}{c}\text { Adjusted } \\
\text { R-squared }\end{array}$ & 0.9244 & 0.9185 & 0.9807 & 0.9964 \\
\hline DW & 1.9952 & 1.9875 & 1.9531 & 1.9624 \\
\hline F statistic & 106.7152 & 110.1990 & 111.1542 & 108.6231 \\
\hline
\end{tabular}

Note: The values in parentheses are $t$, and ${ }^{*},{ }^{* *},{ }^{* *}$ respectively represent the significant levels of the variables at $10 \%, 5 \%, 1 \%$.

to model in order to represent the level of financial development. Among them, model 2 represents financia development by measuring the share of the stock market value of GDP, and model 3 and model 4 are used to examine the effectiveness of using long-term loans balances as an important metric of financial development. The panel data regression results of the four models are shown in the following Table 4.

2) Empirical conclusions

From the estimation results of the model 1, we can find private credit to GDP 
ratio, which represents the depth of financial development in each province, accounts for about 0.0089 , and it is significant at $5 \%$ level. It shows that the level of financial development in a region has a significant positive impact on its outward foreign direct investment. In terms of marginal effect, private credit to GDP ratio can bring an increase of nearly 0.9 percentage points to the outward direct investment flows. The improvement of the level of financial development can indeed promote the expansion of the scale of China's outward foreign direct investment through such channels as convenient financing, which is in line with the previous theoretical analysis and corresponding assumptions.

Among all control variables, the level of economic development represented by the level of per capita GDP has the most obvious effect, with a coefficient of 2.1540. The result of the test shows that it is significant at the level of $1 \%$. It indicates that for every $1 \%$ increase in per capita GDP, the level of outward foreign direct investment flows will increase by $2.15 \%$. This is consistent with the expectations of many scholars that the OFDI cycle theory has been adopted. What's more, many studies also show that the level of OFDI in China is in the rapid economic development's third stage, maybe has become a higher stage. The model 1 demonstrate that the proportion of exports accounted for a significant positive correlation with OFDI, which is in line with our previous analysis that China's export trade can promote the development of OFDI by domestic enterprises. Every $1 \%$ increase in exports to GDP, the level of OFDI has also increased by nearly $1 \%$. Another result also shows that FDI inflow into our country also has a significant promotion effect on China's outward foreign direct investment. The other influencing factor savings level also has a positive effect on China's ODFI. The regression coefficient is 0.6074 , which is significant at $1 \%$ level. That is, we can make an increase in regional savings can promote the level of outward foreign direct investment in the region to increase by nearly 0.61 percentage point.

Model 2 is the result of selecting the index of stock market capitalization to GDP ratio of each province to measure the depth of financial development. That is, the depth of financial development as measured by the ratio of stock market capitalization to GDP. As we can get from the table, the coefficient increased to 0.1165 , the significance has an obvious improvement, which becomes significant at $1 \%$ level. This result shows that the stock market value as a ratio of GDP can also well explain the impact of financial development on China's outward foreign direct investment. This factor increase will result in an increase in the level of OFDI apparently. The regression results of the control variables just changed slightly. Also, the coefficients of economic development did not change too much, with an estimated value of 2.06. We can get other conclusions, such as, the influence of export level on GDP proportion and saving level have been increased and their significance has been enhanced. The effect of foreign direct investment variable haves been on the decline, and the coefficient has become 0.3201 . 
Model 3 and Model 4 respectively represent the impact of the marketization of the distribution of long-terms loan by financial institutions and non-financial institutions on China's outward foreign direct investment. This indicator can be regarded as a measure of the financial structural indicators of a country or region. The overall estimation is in good condition and the adjusted coefficient of determination reaches 0.9807 and 0.9964 , that is, the model can explain $99 \%$ of the change in China's outward foreign direct investment and the DW estimates are 1.9530 and 1.9624 respectively. There is no obvious autocorrelation in these model, $\mathrm{F}$ statistic value is higher, we can see these models are very significant. In the model, the estimated coefficients of core explanatory variable, the loan balance of financial institutions and non-financial institutions to GDP ratio are 0.0215 and 0.0034 . And the t-statistic estimates are significant at the $10 \%$ significance level. This shows that the distribution of credit funds in the region and the existence of direct contact with outward foreign direct investment. The more the lending of credit funds to the non-state sector economy is, the more it can raise the level of OFDI in this region. For every $1 \%$ increase in loans obtained by enterprises in the non-state sector of the economy, they can bring about 2.15 percentage points and 0.34 percentage points increase in outward foreign direct investment. Based on this result, we think that the active part of China's nonstate-owned economy in the main body of OFDI is gradually increasing and its contribution to OFDI is also increasing. Therefore, under the circumstance of more and more capital resources obtained from non-state-owned economy, the level of China's outward foreign direct investment has been significantly improved. The optimization of China's financial structure has become a good effect in promoting the growth and expansion of outward foreign direct investment.

3) Robustness test

In view of the inertia of OFDI, that is, the investment of the previous period is an important determinant of investment in the current period. When thinking this problem, this paper introduces $\mathrm{OFDI}_{-1}$ and uses the method of system GMM to test the robustness. The econometric model is as follows:

$$
\begin{aligned}
\ln O F D I_{i t}= & \alpha_{0}+\alpha_{1} \ln O F D I_{i t-1}+\alpha_{2} F D_{i t}+\alpha_{3} \ln P G D P_{i t}+\alpha_{4} \ln E X_{i t} \\
& +\alpha_{5} \ln F_{i t}+\alpha_{6} \ln S A V E_{i t}+u_{i}+v_{t}+\varepsilon_{i t}
\end{aligned}
$$

Taking into account the interaction between OFDI and trade openness, we consider the lagged period of ODFI as an endogenous variable and this endogenous variable lagged by 2 - 10 orders. The estimation in this paper uses a twostep method and adopts a standard robust deviation. The estimation results are shown in Table 5, where columns (1), (2), (3) and (4) are the ratios of using private credit to GDP, the stock market capitalization as a proportion of GDP, the ratio of loans of financial institutions to GDP, and the ratio of loans of non-financial institutions to GDP as the four indicators.

In this paper, the data structure of 30 provinces in 5 years of the sample fulfilled the requirements of the system GMM “Large N Small T". $\mathrm{AR}_{2}$ was significantly greater than 0.05 , indicating that there was no autocorrelation problem in 
Table 5. Robustness test.

\begin{tabular}{|c|c|c|c|c|}
\hline Variables & $\mathrm{FD}_{1}$ & $\mathrm{FD}_{2}$ & $\mathrm{FD}_{3}$ & $\mathrm{FD}_{4}$ \\
\hline \multirow{2}{*}{ Intercept } & $-2.441^{\star * *}$ & $-2.581^{\star * *}$ & $-3.269^{* * *}$ & $-8.979^{* * *}$ \\
\hline & $(3.8291)$ & $(4.2513)$ & $(10.0046)$ & $(6.7955)$ \\
\hline \multirow{2}{*}{$\operatorname{lnOFDI}_{-1}$} & $0.518^{* * *}$ & $0.600^{\star * *}$ & $0.571^{\star * *}$ & $0.135^{* *}$ \\
\hline & $(7.2381)$ & $(8.1656)$ & $(10.9629)$ & (11.1557) \\
\hline \multirow{2}{*}{$\ln P G D P$} & $0.542^{* *}$ & $0.433^{* *}$ & $0.123^{* *}$ & $0.811^{* *}$ \\
\hline & $(4.2621)$ & $(4.0532)$ & (4.1019) & $(6.3029)$ \\
\hline \multirow{2}{*}{$\ln E X$} & $0.322^{* *}$ & $0.126^{* * *}$ & $0.167^{\star * *}$ & $0.506^{* *}$ \\
\hline & (10.0107) & $(8.2036)$ & $(8.0024)$ & (7.7910) \\
\hline \multirow{2}{*}{$\operatorname{lnFIA}$} & $0.458^{* *}$ & $0.440^{* *}$ & $0.103^{* * *}$ & $0.274^{\star * \star}$ \\
\hline & $(6.9013)$ & $(2.1306)$ & (7.9916) & $(7.2341)$ \\
\hline \multirow{2}{*}{$\operatorname{lnSAVE}$} & $0.151^{\star *}$ & $0.154^{\star}$ & $0.903^{*}$ & $0.317^{* *}$ \\
\hline & $(1.0129)$ & $(0.0052)$ & (5.1330) & $(6.0134)$ \\
\hline \multirow{2}{*}{$\mathrm{FD}_{1}$} & $0.395^{\star}$ & & & \\
\hline & $(4.3677)$ & & & \\
\hline \multirow{2}{*}{$\mathrm{FD}_{2}$} & & $0.188^{\star}$ & & \\
\hline & & $(6.1039)$ & & \\
\hline \multirow{2}{*}{$\mathrm{FD}_{3}$} & & & $0.470^{\star *}$ & \\
\hline & & & $(9.5152)$ & \\
\hline \multirow{2}{*}{$\mathrm{FD}_{4}$} & & & & $0.206^{* *}$ \\
\hline & & & & $(5.6061)$ \\
\hline $\mathrm{AR}_{1}$ & 0.005 & 0.0012 & 0.000 & 0.000 \\
\hline $\mathrm{AR}_{2}$ & 0.178 & 0.065 & 0.094 & 0.263 \\
\hline Hansen & 0.326 & 0.352 & 0.125 & 0.367 \\
\hline $\begin{array}{l}\text { Number of tool } \\
\text { variables }\end{array}$ & 28 & 28 & 28 & 28 \\
\hline $\begin{array}{l}\text { Number of } \\
\text { provinces }\end{array}$ & 30 & 30 & 30 & 30 \\
\hline
\end{tabular}

Note: The values in parentheses are $t$, and ${ }^{*}{ }^{* *},{ }^{* *}$ respectively represent the significant levels of the variables at $10 \%, 5 \%, 1 \%$.

the original sequence. Hansen test was significantly higher than 0.05 . Meanwhile, the number of samples is 28 and less than the number of province which is 30. Hansen test does not have the problem of over-checking the Hansen test due to too many tool variables, so there is no over-identification problem. In the meantime, we think that delayed outward foreign direct investment is significant at the level of $1 \%$.

From the results, we find that the level of financial development still has a significant impact on the size of China's outward foreign direct investment, considering the one-period OFDI. The indexes of this four models are significant at the levels of $1 \%, 1 \%, 5 \%$ and $5 \%$, respectively, without loss of generality. Therefore, we can tentatively confirm that the series of empirical tests conducted before this article have statistical robustness in principle and the results are highly 
reliable.

\section{Conclusion}

Based on the results of comprehensive empirical analysis, we find that the regression analysis based on panel data of various provinces in our country can get better results on the factors affecting China's outward foreign direct investment. First of all, the index of indicators of financial development, that is, the proportion of total private credit, has a significant positive impact on OFDI in all regions. Increasing the share of it can promote the development of outward foreign direct investment. Second, the use of a more closely linked stock market value to GDP as a proxy for alternative returns is more pronounced and the impact of this variable on regional outward foreign direct investment is greater. In addition, the degree of marketization of the distribution of credit funds measured by the ratio of corporate loans also plays a very important role in regional OFDI. The allocation of more credit facilities to the more effective non-state sector can more effectively promote an increase in OFDI. Finally, the regression results of the relationship between other variables and OFDI are basically the same as the previous research analysis. It must be pointed out that the level of economic development is still the most important factor that affects the outward foreign direct investment in various regions of our country. China is still in the stage of rapid growth of overseas direct investment driven by the rapid economic development. App art from this, the level of exports, the level of foreign investment attraction and the level of savings in the region can promote the outward foreign direct investment.

\section{Recommendations}

Combined with the theoretical and empirical analysis of this article, we can propose the following policies in order to promote the development of China's outward foreign direct investment:

First, we should further deepen the reform of the financial system in two directions. One is to guide the flow of credit funds to more real estate which has good development prospects; the other is to guide more credit to the dynamic allocation of small and private enterprises. Relying on supporting the development of real economy, financial system will further improve the investment and financing functions of the financial system, optimize the structure of financial markets and promote the marketability of capital allocation.

Second, the imbalances in the development of various regions may become bottlenecks in the further development of China's outward foreign direct investment. To coordinate regional economic development and narrow the gap between the economic development bases in different regions in China, especially the gap between financial services, is one of great significance to our country's outward foreign direct investment to a higher level. The development of the real economy is still the engine in most of China's current activities. From rais- 
ing the quality and optimizing the structural dimension to elevating the level of economic development and maintaining the speed of economic development, it will be conducive to further enhancing the level of China's foreign direct investment.

Third, promoting the full flow of capital in the capital market while maintaining the effective and healthy development is an important measure to promote economic development. Although China's capital market has achieved tremendous development, it is still imperfect. The system of administrative examination and approval, a large number of non-tradable shares and irregular market transactions all greatly limit the ability of Chinese enterprises to raise capital from the capital market. The regulation of the capital market must be enhanced so as to prevent the volatility of domestic stock prices and the influx or outflow of a large amount of off-site funds. In order to achieve smooth investment and reduce the adverse economic impact caused by the constant hot money, it's urgent to improve the legal system in capital markets and financial enterprises.

Thus, in our country, the current total savings and trade openness rank the highest in the world and the level of economic development is growing rapidly. The level of financial development is an important factor that accelerates China's outward foreign direct investment. Therefore, we should further perfect our financial market structure, change the current situation of over-reliance on stateowned bank financing and insufficient vitality of the capital market so as to further enhance and boost our ability to make direct overseas investments more effectively. In the future, we are very hopeful to change our country's disadvantageous position and further consolidate an advantageous position in the current international investment system.

\section{References}

[1] Zhang, S.L., Yang, Z. and Han, L. (2012) China's Outward Foreign Direct Investment: Government-Driven or Financial-Driven. Financial Theory and Practice, 10.

[2] Wang, X. (2013) Financial Crisis and Foreign Direct Investment in Developing Countries. International Economic Review, 1.

[3] Jiang, H. (2014) Relationship between Financial Development, Economic Openness and Foreign Direct Investment. Journal of Central University of Finance and Economics, 7.

[4] Mckinnon, R.I. (1973) Money and Capital in Economic Development. Journal of World Business.

[5] Beck, T. and Levine, R. (2004) Stock Markets, Banks, and Growth: Panel Evidence. Journal of Banking and Finance, 28, 423-442. https://doi.org/10.1016/S0378-4266(02)00408-9

[6] Dunning, J.H. (1981) Explaining the International Direct Investment Position of Countries: Towards a Dynamic or Developmental Approach. Review of World Economics.

[7] Berman, N. and Hericourt, J. (2010) Financial Factors and the Margins of Trade: Evidence from Cross-Country Firm-Level Data. Journal of Development Econom- 
ics, 206-217. https://doi.org/10.1016/j.jdeveco.2009.11.006

[8] Manova, K. (2013) Credit Constrains, Heterogeneous Firms, and International Trade. Review of Economics Studies, 2.

[9] Shen, H.B., Kou, H. and Zhang, C. (2010) An Empirical Study of Financial Development, Financing Constraints and Corporate Investment. China Industrial Economics, 6.

[10] Zhang, J. and Jin, Y. (2005) Redetection of the Relationship between China's Deepening of Finance and Productivity: 1987-2001. Economic Research, 11.

[11] Guan, J. and Wang, X. (2007) Study on Determinants of China's Foreign Investment. China Soft Science, 2.

[12] Lin, Z., Chen, Y. and Qin, X. (2012) Determinants of China's Foreign Investment: Based on the Integration of Resources and Institutions Empirical Analysis of Perspectives. Management World, 8.

[13] Guo, J. and Huang, B. (2010) Savings, Corporate Governance, Financial Structure and Foreign Direct Investment: An Empirical Study Based on Cross-Country Comparison. Financial Research, 2, 76-90.

[14] Yu, C., Ge, H. and Cao, J. (2011) Theoretical Analysis and Empirical Test on the Determinants of China's Foreign Direct Investment. Academic Forum, 6.

[15] Tao, P., Jun, H. and Liu, Z. (2013) Formulation and Perfection Proposals for China's Foreign Direct Investment Policy System. International Trade, 9.

[16] Yang, T., Tian, Y. and Zou, H. (2014) Characteristics and Trends of China's Outward FDI in 2013-2014. International Economic Cooperation, 1.

[17] Wang, W., Sun, D. and Yang, J. (2013) Whether Financial Development Can Promote Foreign Direct Investment: An Empirical Analysis Based on Panel Quantiles. International Trade Issues, 9.

[18] Xiang, B. (2009) Empirical Study on the Characteristics of the Host Country and China Outward Foreign Direct Investment. Journal of Quantitative Economy and Technology Economics, 7, 33-46.

[19] Huang, L., Xu, L. and Ran, M. (2009) Financial Development, Foreign Direct Investment and Technological Progress: A Threshold Model Analysis Based on China's Provincial Panel Data. Journal of Management Engineering, 3.

[20] Huang, Z., Wan, X. and Xu, C. (2015) The Impact of Financial Development on China's Foreign Direct Investment: An Empirical Analysis Based on Provincial Panel Data. World Economics and Politics Forum, 1.

[21] Yu, G. and Yuan, D. (2014) Financial Development Is a Booster or a Stumbling Stone to China's Outward Foreign Direct Investment: An Empirical Study Based on Quantitative and Quality Dimensions. International Trade Issues. 